\title{
Errata: Princípios ecfrásticos em Paisagens com figuras, de João Cabral
}

\section{Errata: Ecfrastic aspects in Paisagens com figuras, de João Cabral}

\section{Errata: Los principios ecfrásticos en Paisagens com figuras, de João Cabral}

iD (9) Fabiane Renata Borsato

Universidade Estadual Paulista Júlio de Mesquita Filho (UNESP), Araraquara, São Paulo, Brasil. ILCML - Instituto de Literatura Comparada Margarida Losa - Universidade do Porto, Porto, Portugal E-mail: fabiane.borsato@unesp.br

O artigo original foi publicado em 13 de março de 2020. https://www.revistas.ufg.br/sig/article/view/58769>.

Resumo: É objetivo deste artigo analisar os poemas da obra Paisagens com figuras, de João Cabral de Melo Neto, que descrevem localidades da Espanha e do Nordeste brasileiro, para compreensão dos princípios ecfrásticos de construção dessas paisagens e de seus efeitos de sentido, assim como o compromisso ético do eu poético no processo de leitura das paisagens e de instauração da linguagem que as representa.

Palavras-chave: Poesia brasileira. Écfrase. João Cabral de Melo Neto. Paisagens com figuras.

Abstract: This paper aims to analyze poems of the work Paisagens com figuras, by João Cabral de Melo Neto, that describe landscapes of Spain and Northeast of Brazil, to understand the mechanisms of the ekphrasis of construction of these landscapes and their effects of sense, as well as the ethical commitment of the enunciator in the process of object reading and establishing the language that represents it.

Keywords: Brazilian poetry. Ekphrasis. João Cabral de Melo Neto. Paisagens com figuras.

Resumen: Análisis de poemas de la obra Paisagens com figuras, de João Cabral de Melo Neto, que describen localidades de España y Nordeste de Brasil, para estudio de los mecanismos ecfrásticos de la 
paisaje y de sus efectos de sentido, también del compromiso ético del enunciador con la lectura del objeto y la instauración del lenguaje que lo representa son los objetivos del artículo.

Palabras-clave: Poesia brasileña. Écfrasis. João Cabral de Melo Neto. Paisagens com figuras.

Submetido em 28 de maio de 2019.

Aceito em 23 de setembro de 2019.

Publicado em 30 de abril de 2021. 


\title{
Acerca da écfrase e de Paisagens com figuras
}

Para o estudo da écfrase é importante compreender suas transformações e relações com o contexto de formação da literatura e das artes. Cada novo emprego desse procedimento o atualiza e ressignifica, motivo por que não há teoria fechada e imutável da écfrase, tampouco pode ela prescindir da prática analítica de poemas para conhecimento de seus modos de emprego e dos sentidos deles advindos, sendo fundamental refletir sobre o princípio da écfrase em relação à retórica do texto poético.

No livro X (601b) da obra "República", Platão reconhece que o poeta trabalha com palavras de modo singular e que a expressão convence o leitor de seu êxito na imitação de outras artes:

\begin{abstract}
O poeta, por meio de palavras e frases, sabe colorir devidamente cada uma das artes, sem entender delas mais do que saber imitá-las, de modo que, a outros que tais, que julgam pelas palavras, parecem falar mesmo muito bem, quando dissertam sobre a arte de fazer sapatos, ou sobre a arte da estratégia, ou sobre qualquer outra com metro, ritmo e harmonia. Tal é a grande sedução natural que estas têm, por si sós. (PLATÃO, "2001", p. 461)
\end{abstract}

Esta questão evidencia o campo polêmico de estudo da écfrase, marcada pelo milenar problema da mimese concebida como imitação do mundo ou da própria linguagem, bem como pelos sucessivos estudos sobre a arbitrariedade e a naturalidade do signo. No cerne de tais discussões está a distinção entre artes do espaço e artes do tempo, e o fato de que cada arte apresenta objeto próprio e maior ou menor capacidade de representação das coisas no mundo. Sendo assim, o princípio da écfrase problematiza a natureza das artes, as relações com o referente, a capacidade icônica de fixação espacial do objeto no fluxo temporal da linguagem verbal e as equivalências entre palavra e objeto visual, conforme 
Princípios ecfrásticos em Paisagens com figuras, de João Cabral

Fabiane Renata Borsato

atesta Joana Matos Frias no texto de apresentação do dossiê "A écfrase na poesia moderna e contemporânea", da Revista e-Lyra, n. 8:

\begin{abstract}
O sentido teórico-crítico actual do conceito de écfrase pouco ou nada preserva da significação originária da ekphrasis enquanto exercício retórico indissociável da mimesis e da enargeia; nessa acepção matricial, não só as artes miméticas são artes de fazer imagens (icásticas ou fantásticas, de acordo com a conhecida tipologia de Platão apresentada n'O Sofista) suscitadoras de um efeito de evidência, como o princípio ecfrástico se configura em diversos tipos textuais que alternam entre a mais pura descrição, a narração e a prosopopeia (Spitzer; Hagstrum): histórica e tradicionalmente, portanto, a écfrase nem resulta de uma dupla mimesis (cf. Riffaterre), nem é um género, mas antes um princípio (cf. Krieger). (FRIAS, 2016, p. 33)
\end{abstract}

No texto "Diálogo y comparación entre las artes", Antonio Monegal afirma que a écfrase também está fundamentada "en la invocación y la evocación de la visualidad" (MONEGAL, 2000, p. 18). O diálogo intertextual evoca, de modo único, o que está ausente e se faz presente na linguagem da poesia. Para tanto, o poeta elege o movimento que a poesia assumirá para a construção da visualidade e de sua ficção literária, sendo a écfrase literária um modo singular de leitura e interpretação de uma obra de arte ou de um objeto. Michel Riffaterre, em seu estudo sobre a recepção da écfrase intitulado "La ilusión de écfrasis", afirma que ela não copia o objeto visual, tampouco o transcreve em palavras, mas o constrói como projeto do escritor: "No hay imitación sino intertextualidad, interpretación del texto del pintor e del intertexto del escritor." (RIFFATERRE, 2000, p. 174). Outra característica da écfrase, mencionada por Riffaterre, é que ela "tiende a seleccionar todo aquello que el cuadro excluye." (RIFFATERRE, 2000, p. 164), tornando relevantes os sentidos promovidos pela écfrase, no novo contexto, em relação ao objeto e à situação apresentados.

Neste trabalho, estudaremos o emprego do princípio ecfrástico na obra Paisagens com figuras (1954-1955), de João Cabral de 
Princípios ecfrásticos em Paisagens com figuras, de João Cabral

Melo Neto, preferindo pensá-la não como a capacidade que a palavra possui de imitar objetos das artes visuais, mas de acordo com "o modo como o objecto é dado a ver, já que a ekphrasis, figura por excelência da enargeia, tem a sua origem no desejo semiótico pelo signo natural, isto é, na ambição de obter the world captured in the word (Krieger)" (FRIAS, 2016, p. 34).

A abordagem da écfrase literária que aqui se quer não opta pelo polo da autorreferencialidade total, para a qual a literatura não aborda outro fato senão a si mesma, tampouco opta pelo da imitação do objeto. A tensão entre estes dois polos deve oferecer a esta leitura um olhar mais dialético, em que a literatura possa assumir seu jogo discursivo promotor da ilusão referencial. Sendo assim, neste trabalho a écfrase será abordada enquanto princípio periegético para a análise de alguns textos poéticos de Paisagens com figuras, concentrando esforços no estudo das descrições topográficas da Espanha e do Nordeste brasileiro e na compreensão dos mecanismos ecfrásticos de construção dessas paisagens e de seus efeitos de sentido, advindos do cruzamento, no poema, de memória, história e representação da geografia observada pelo eu poético-leitor das paisagens.

João Cabral de Melo Neto publica, em 1955, as obras Paisagens com figuras, Morte e vida Severina, Uma faca só lâmina. A primeira e a última guardam entre si a peculiar preocupação com a construção da imagem e de sua relação com o real. O longo poema Uma faca só lâmina afirma o fracasso da imagem diante da primazia do real: "por fim à realidade,/ prima, e tão violental que ao tentar apreendê-la/ toda imagem rebenta." (MELO NETO, 1999, p. 215, grifo do autor). Entretanto, ao constituir na linguagem a imagem da bala-faca-relógio, o poema alcança seu papel ético de promover a consciência sobre a realidade, na leitura complexa e singular empreendida pelo eu poético: "e afinal à presença/ da realidade, prima,/que gerou a lembrança/ e ainda a gera, ainda," (MELO NETO, 1999, p. 215, grifo do autor). As etapas de construção da imagem no poema Uma faca só lâmina compreendem realidade prima - lembrança - imagem/linguagem, bem como a lição de que a imagem 
Princípios ecfrásticos em Paisagens com figuras, de João Cabral

não pode tentar apreender a realidade, sob risco de autodestruição e ingenuidade realista.

Em Paisagens com figuras, as palavras alcançam, pelo princípio da écfrase, o aspecto ético ao apresentar o homem e sua condição de existência na paisagem. Recurso frequentemente empregado pelo poeta, a écfrase não apresenta a intenção de pintar com palavras realidades ou objetos, mas é um procedimento metapoético para discussão e construção de paisagens e figuras poéticas, existentes somente no espaço do poema, na linguagem da poesia, embora elas guardem uma relação ético-reflexiva com espaços e questões apresentadas.

Além disso, Cabral realiza o encontro de tempos e paisagens diversas, associa signos semanticamente distantes, justapõe elementos díspares para entre eles estabelecer equivalências por similitude e contraste, empreende um percurso que parte da percepção e compreensão do objeto tematizado e da linguagem que o tematizará, visando ao alcance da linguagem-objeto para que seja, segundo João Alexandre Barbosa em A imitação pela forma, “[...] possível tratar da realidade através do poema, isto é, através de uma forma, de uma linguagem que, para a sua estruturação, não despreza, antes acentua, a existência do objeto." (BARBOSA, 1975, p. 226).

A poética da aprendizagem da linguagem da poesia, empreendida por João Cabral desde a primeira obra, funda-se na observação e tentativa de conhecimento do objeto e se desenvolve rumo à aprendizagem da linguagem capaz de representação/interpretação e à forma de percepção do objeto. Com base nesta premissa de seu projeto poético, Cabral cria uma poesia essencialmente prismática que decompõe o objeto tematizado num espectro de pontos de vista e enquadramentos, fazendo uso de inusitadas associações com outros objetos, pautadas no desdobramento das imagens criteriosamente discutidas em seu processo de constituição do poema, conforme realça Benedito Nunes na primeira obra crítica de fôlego sobre a poesia de João Cabral: 
Princípios ecfrásticos em Paisagens com figuras, de João Cabral

O ato operatório, que essa textura prismática exige, e que pode ser considerada constante técnica da construção da poesia em João Cabral, consiste em decompor a "ideia" em unidades descritivas e recompô-la na estrutura do discurso. Mas sendo essas unidades faces complementares que constituem o tema, pode-se dizer então que a composição poética se constrói projetando-se num objeto, e construindo nele o seu próprio sentido temático. (NUNES, 1971, p. 109)

Na obra Paisagens com figuras, o mecanismo de composição prismática é reiterado com foco nos diálogos interculturais Nordeste brasileiro-Espanha. O processo de leitura e aprendizagem da paisagem permite a Cabral, nessa obra, relacionar as experiências nordestina e espanhola, sejam elas geográficas ou culturais.

Cabral trabalha a poesia num mecanismo de inscrição de tese e contraposição à tese, sendo importante analisar, nos poemas, o modo de enunciação adotado pelo eu poético; os campos semânticos reiterados para a elaboração da écfrase; o movimento do olhar do eu poético na leitura das paisagens; a ordem dos objetos e sua forma estética de apresentação; a relação entre écfrase e reescrita, presente especialmente nos versos de retomada, cujo intuito parece ser o de detalhar a descrição do objeto e lhe oferecer integridade. $O$ estudo destes elementos deve gerar compreensão da poesia crítica de João Cabral e consciência da complexidade da linguagem-objeto e do objeto por ela representado.

\section{Paisagens com figuras: o homem e a topografia}

Paisagens com figuras contém dezoito poemas sobre temas que giram em torno da cultura e da geografia espanhola e nordestina. É possível dividi-la em três núcleos temáticos. Aquele que compreende um maior número de poemas, totalizando nove, sobre paisagens e topografias espanholas e pernambucanas, com foco nos habitantes do local. O segundo núcleo temático contém 
Princípios ecfrásticos em Paisagens com figuras, de João Cabral

cinco poemas sobre a cultura espanhola, incluindo poetas, toureiros e o canto andaluz. Três cemitérios pernambucanos constituem o terceiro conjunto de poemas, tema recorrente na obra de Cabral depois de Paisagens com figuras, predominantemente nos livros Quaderna, Dois parlamentos e Agrestes.

Nota-se, em alguns poemas da obra, especialmente naqueles focados nos aspectos geográficos do Nordeste e da Espanha, eus poéticos situados em locais estratégicos para dar a ver os desníveis topográficos que, uma vez descritos, construirão a dimensão geográfica do lugar e alcançarão os aspectos humanos.

Este trabalho realizará a leitura dos poemas do primeiro bloco, em que a construção das topografias espanhola e pernambucana assume viés comparativo. Trata-se dos poemas "Pregão turístico do Recife", "Medinaceli", "Imagens em Castela", “O vento no canavial", "Vale do Capibaribe", "Alto do Trapuá", "Volta a Pernambuco", "Outro rio: o Ebro" e "Duas paisagens". A seleção destes poemas deve-se ao fato de serem todos eles focados, inicialmente, na topografia da Espanha ou de Pernambuco para, gradativamente, tratar do homem que habita estas paisagens. Além disso, o poema de encerramento do livro, "Duas paisagens", adota o princípio ecfrástico comparativo, lançando o olhar sobre as paisagens da Catalunha e de Pernambuco e funcionando como síntese dos procedimentos presentes nos outros poemas do mesmo bloco.

\section{"Pregão turístico do Recife" e "Alto do Trapuá": contra- dições das duas paisagens}

Os poemas "Pregão turístico do Recife" e "Alto do Trapuá" apresentam algumas coincidências quanto à construção da écfrase, ambos descrevem duas paisagens com a segunda delas composta pelo homem em sua situação vulnerável de indigência e desumanidade. Além disso, os eus poéticos assumem a terceira pessoa e instauram interlocutores que recebem lições sobre os modos de 
apreensão das paisagens. O olhar dos eus poéticos move-se verticalmente, de cima da montanha até o interior do rio lamacento, e assume visão panorâmica para abarcar a paisagem de leste a oeste ou prefere o primeiro plano para ajustar a imagem à condição da espécie local. Nos dois poemas, a écfrase compõe imagens complexas e contraditórias das paisagens pernambucanas.

Em "Pregão turístico do Recife", mar é associado metaforicamente à montanha, dela o mar herda a verticalidade e também o caráter de acidente geográfico; enquanto os sobrados são metaforicamente nomeados "ombros calcários" em relação metonímica de disputa do espaço: "Aqui o mar é uma montanha/ regular, redonda e azul,/ mais alta que os arrecifes/ e os mangues rasos ao sul.// [...] Na cidade propriamente/ velhos sobrados esguios/ apertam ombros calcários/ de cada lado de um rio." (MELO NETO, 1999, p. 147). A construção da paisagem desemboca no rio e na gente que vive às suas margens, elementos antes poetizados nas obras $O$ cão sem plumas e $O$ rio. Pelo recurso metonímico, João Cabral implica os dois objetos, rio e homem - os termos indigente, sangue-lama, marcha, estagna, mucosa podem ser atribuídos a rio ou a gente -, levando a inferir que uma mesma condição os interliga: "E neste rio indigente,/ sangue-lama que circula/ entre cimento e esclerose/ com sua marcha quase nula,// e na gente que se estagna/ nas mucosas deste rio,/ morrendo de apodrecer/ vidas inteiras a fio," (MELO NETO, 1999, p. 147, grifo nosso). Em suma, neste poema, o eu poético situado em local estratégico tem acesso a uma vista superior da paisagem, composta pelo ponto culminante mar-montanha. Os pontos mais baixos são formados por arrecifes e mangues e, na estrofe 3, a paisagem natural perde foco para dar lugar à cidade e a seus velhos sobrados. O olhar do eu poético des-loca-se para baixo e posiciona-se frontalmente, descrevendo a di-nâmica de construção dos sobrados apertados porque dispostos lado a lado, ombro a ombro. Tanto ao mar quanto aos sobrados há a possibilidade de aprendizagem porque possuem um traçado preciso e uma arquitetura equilibrada, respectivamente. $\mathrm{O}$ mesmo não se pode afirmar sobre o rio e o homem que vive à sua margem, pois a focalização do rio indigente evidencia um descenso topográfico que envolve questões 
sociais e econômicas, e suas contradições em Recife.

O título do poema sintetiza uma cidade turística a clamar pelo negócio e comércio para, em seguida, nas quatro primeiras estro-fes, apresentar a imagem de cartão-postal, composta de mar, arrecifes, arquitetura assobradada. A quinta estrofe tanto desloca

o eu poético para perto do rio quanto surge como um adendo, marcada pela conjunção aditiva " $\mathrm{e}$ " que vem somar à paisagem anterior outra imagem nada turística ou comerciável: a do rio e de sua miséria. A estrofe seis retoma a função conativa e ensina ao interlocutor-turista uma nova lição, a da valorização da vida humana: "podeis aprender que o homem/ é sempre a melhor medida./ Mais: que a medida do homem/ não é a morte mas a vida." (MELO NETO, 1999, p. 147).

As estrofes finais adicionam à paisagem turística outra bem diversa, de privação e morte a que são submetidos homens e rio, motivo por que a écfrase do poema estabelece equivalências com a condição sistêmica recifense de manutenção da miséria para preservação das hierarquias sociais dos que vivem ombro a ombro, nos "velhos sobrados esguios". A écfrase é um mecanismo de leitura dessas paisagens e de suas figuras para instauração da aprendizagem: "[...] para fazer ver a paisagem e a figura, a linguagem do poema tem de fazer-se intensificadora, e não apenas nomeante, da experiência." (BARBOSA, 1975, p. 132). Antônio Carlos Secchin, na obra crítica João Cabral de Melo Neto: uma fala só lâmina, analisa o movimento do poema como aquele que capta o padrão matemático da paisagem e chega à complexa organização do Recife e à estagnação do homem não turístico, sendo este "'outro Recife' (o não turístico), cuja impura umidade contrasta com a assepsia mineral das primeiras quadras" (SECCHIN, 2014, p. 101), o objeto de aprendizagem.

"Alto do Trapuá" é um poema ecfrástico que, como "Pregão turístico do Recife", descreve a paisagem pernambucana sob ângulos diversos. A vista superior é instaurada no início do poema, mas há um dado novo, o perímetro deste olhar abrange os 360 
Princípios ecfrásticos em Paisagens com figuras, de João Cabral Fabiane Renata Borsato

graus panorâmicos para, no final, selecionar a visão telescópica capaz de apreender até as formigas no grão da espiga. Nesse poema, o interlocutor situado próximo ao eu poético, com ele empreende uma incursão panorâmica pela região. O percurso parte da informação sobre a localização geográfica do Engenho Trapuá para sugerir o caminho da direita que levará à igreja e ao mirante, ambos situados na parte montanhosa da região. Além da altura em que estão eu poético e interlocutor ser propícia à apreensão panorâmica da localidade, o verão e sua luminosidade favorecem o alcance da visão.

A segunda estrofe do poema continua a desenvolver a écfrase, agora focalizando o oeste da paisagem. Nesta região está localizado o Agreste, bem como plantações e mato. A estrofe é fortemente marcada pela enumeração para composição da paisagem: algodão, mamona, abacaxi, agave, palmatória, mandioca, avelós. Nesse momento, Cabral opta pela metáfora fazendo equivaler algodoal e cabeleiras encardidas, abacaxis e sabres metálicos, agave e falo, avelós e cão ou alcaide; imagens que apresentam semas da sexualidade e da defesa da propriedade e que a outros semas se juntarão para denunciar a situação desumana do habitante local, apesar da fertilidade das terras.

Na estrofe três, a focalização é direcionada para o leste, onde imperam os canaviais. O canavial equivale ao feminino por sua capacidade de engendrar mais cana e estender seu território. Para sustentar esta imagem, Cabral evoca outros campos semânticos, tais como aristocracia, exército, enchentes, reiterando com estas palavras os sujeitos interessados na expansão do canavial pela paisagem.

À variedade paisagística, Cabral interpõe o elemento imutável, de aparência humana. Para descrever este elemento, há um movimento pendular que oscila entre signos que referenciam o humano e o inumano, o cheio e o vazio. Assim, aparência humana soma-se a torpor de vegetal; ventres vazios e cheios de fome assumem a forma côncava até a adolescência e convexa na idade adulta. Essa descrição abdominal promove estranhamento, pois a fome é 
construída pela paradoxal condição de ventre cheio e vazio. O ventre baldio, onde há ausência plena de conteúdo, acompanha o ser de aparência humana durante a infância e a adolescência, sendo a fome seu único conteúdo. Além disso, os signos "sem alimento, baldio, vazio, ausência, fome, devoluto, côncavo, convexo, franzina, consuntivo" reforçam o campo semântico da falta e da miséria a que está submetido o abdômen do ser descrito e, por extensão, toda a sua existência. Esta situação encontra o ápice nos versos: "e o que parecia fruta/ se fará palha absoluta." (MELO NETO, 1999, p. 162). Apesar disso e à revelia desta falta, o ser se multiplica e tal fertilidade poderia significar alguma esperança, não fosse imediatamente questionada pelo emprego da conjunção adversativa e da informação sobre a condição indigente da espécie: "Mas é uma espécie indigente,/ é a planta mais franzina/ no ambiente de rapina,/ e como o coqueiro, consuntivo,/ é difícil na região seu cultivo." (MELO NETO, 1999, p. 162). A condição desfavorável de indigência é descrita em versos que oscilam entre signos que remetem à fauna ou à flora. Quanto à espécie ameaçada, Cabral prefere atribuir semas da flora, tais como planta, coqueiro, cultivo; à outra espécie, àquela que ameaça, Cabral atribui semas da fauna, ampliando sua capacidade de atuação ao se referir a um "ambiente de rapina" que expõe a flora indefesa a um predador voraz.

A última estrofe do poema retoma a imagem das lentes de aproximação promovidas pelo verão, anunciado no início do poema. A precisão destas lentes gera uma nova imagem, construída por comparação: a da formiga de ar racional que se contrapõe ao semblante pouco racional da espécie de aparência humana acima descrita. Os cinco últimos versos do poema promovem gradativo ajuste da imagem até o plano detalhe: "até uma espiga sem grão,I até o grão de uma espiga,/ até no grão essa formiga/ de ar muito mais racional/ que o da estranha espécie local." (MELO NETO, 1999, p. 162). A écfrase em "Alto do Trapuá" denuncia a condição dos homens desumanizados, habitantes miseráveis do local. Para isso, seleciona criteriosamente o léxico do poema, optando por palavras que sejam da natureza do local e da condição descrita: 
O que se busca é o componente sistêmico que subjaz no dado empírico, para que a perícia engenheira do poeta possa transformá-lo num modelo reduzido e geometrizado. Rejeitando um discurso que se quer somente uma transparência subjugada ao império da referencialidade, João Cabral registra também o peso das imagens que recobrem o real: nesse sentido se pode falar de uma paisagem com figuras. (SECCHIN, 2014, p. 112)

Ao optar pelo desenvolvimento sistemático das imagens, ao discuti-las verso a verso, João Cabral promove seu desdobramento e uma consequente trama de sentidos pautada na crítica à situação precária dos homens da região canavieira. Em Paisagens com figuras, cada imagem mantém relação com a anterior, com a subsequente e com a representação da paisagem descrita: “Orientando-se para o real das paisagens e das figuras, imitando o sentido da forma que desenha com traços grossos de humanidade, a linguagem do discurso poético é também o discurso da linguagem na medida em que submete os seus dados à crítica da função representativa da palavra." (BARBOSA, 1975, p. 145).

Ao expor os mecanismos de composição da écfrase e do poema, Cabral cria, inclusive, seu próprio conceito de metáfora, marcado tanto pela similaridade quanto pela contiguidade, traço convencionalmente atribuído à metonímia. Sendo assim, cada metáfora apresentada por Cabral, de modo metapoético, mantém com as demais metáforas inusitadas relações de equivalência e de implicação, promovendo a relação entre os dois polos de organização da linguagem, seleção e combinação, conforme insistia Jakobson (1995) em seus estudos sobre poesia. Estes procedimentos justificam-se pela opção de Cabral por uma ética poética que não falseie a realidade enunciada, mas promova leituras complexas e críticas. 


\section{"Medinaceli" e "O vento no Canavial": espaços e tempos duplicados}

Os poemas "Medinaceli" e "O vento no Canavial" contrapõem dois tempos. O primeiro emprega a memória histórico-cultural para tratar do movimento de descenso topográfico e social da cidade. O segundo para dividi-la em duas paisagens, uma estática e outra atuante. Ambos os poemas utilizam esses recursos para implicar paisagem e povo. Entretanto, enquanto "Medinaceli" enfatiza o processo de evasão de sua gente; a paisagem do canavial é associada à "multidão/ lutando na praça cheia." (MELO NETO, 1999, p. 151).

"Medinaceli (Terra provável do autor anônimo do Cantar de Mio (id)" e a tríade de poemas sobre os cemitérios pernambucanos são os únicos a apresentar subtítulo em Paisagens com figuras. Contudo, enquanto o subtítulo da tríade localiza geograficamente os cemitérios nas cidades pernambucanas, o subtítulo de "Medinaceli" instaura uma nova figura na paisagem, à maneira antonomástica, funcionando como perífrase motivadora de traços histórico e épico atribuídos à cidade de Medinaceli, "terra provável do autor anônimo do Cantar de Mio Cid", sendo de ordem cultural a sua presença. Os adjetivos "provável" e "anônimo" prenunciam as elipses e as incertezas históricas que rondam o poema e, por implicação, a cidade.

Após a dupla titulação, o poema se desdobra em dois tempos, passado e presente, para a descrição da condição atual de Medinaceli e da obra Cantar de Mio Cid. Assim, as quadras são compostas por redondilha maior e rimas toantes nos versos pares, à maneira do Romanceiro advindo do Cantar de gesta. Composto de nove estrofes, o poema pode ser dividido em dois conjuntos, um formado pelas estrofes 2 a 5 que se referem ao tempo passado de edificação da cidade de Medinaceli, e um outro que trata da situação atual de esvaziamento da cidade, descrita nas estrofes 1 e 6 a 9. A interpolação do passado da cidade é significativa, pois explica a situação em que se encontra Medinaceli no presente e as rela- 
Princípios ecfrásticos em Paisagens com figuras, de João Cabral

ções com a história épica dos tempos de Mio Cid. A localização geográfica da cidade e sua edificação para fins bélicos tornaram-na local estratégico no passado, mas essas guerras e conquistas de outrora não conseguiram promover o desenvolvimento da cidade que, no presente do sujeito da enunciação do poema, encontra-se em processo de esvaziamento de sua população.

A primeira estrofe compõe a imagem da Medinaceli esquelética e em situação hemorrágica. $\mathrm{O}$ eu poético assume o contra-plongée que remete tanto à superioridade da cidade em tempos de conquista cristã quanto à atual situação hemorrágica, vislumbrada no enquadramento. As estrofes 2 a 5 remetem ao passado e evidenciam a topografia montanhosa do entorno da cidade, localizada na fronteira dos reinos de Castela, Aragão e mouro, no coração da Espanha. Medinaceli ainda é metáfora do reino de Castela-Leão, representado pela figura "leão de pedra". Situada na província plana de Castela, mas com papel bélico central no "tabuleiro" das guerras (estrofe 3), sua topografia elevada - "(nesse elevado plantão)" - emoldura a situação estratégica tal qual os parênteses emolduram a descrição de Medinaceli e recriam a figura anterior do leão de pedra, ambos a postos para a batalha.

As estrofes 4 e 5 interpolam Medinaceli geográfica e politicamente, anunciando, de modo elíptico, interesses e estratégias políticas dos reinados de Castela, Leão e Aragão. A descrição da construção de Medinaceli recebe dois adjetivos significativos: "armados" e "abençoados", representando a nobreza e a igreja, respectivamente, bem como seus interesses pela cidade de Medinaceli como lugar estratégico para as conquistas territoriais dos reinos. Outros dois termos desta estrofe - "lograram" e "deserto" - reforçam o engano e a aridez da cidade e prenunciam o destino futuro de Medinaceli.

A sexta estrofe retoma o tempo presente, o aqui e agora da enunciação, para reforçar a imagem da esvaída Medinaceli da estrofe 1. A dinâmica da cidade é outra no tempo presente, marcada pela descensão de seus habitantes rumo a espaços mais gloriosos. Seus monumentos, praças, sua arquitetura rota e esvaída de sentido são descritos como objetos em presença física que, lado a lado 
Princípios ecfrásticos em Paisagens com figuras, de João Cabral Fabiane Renata Borsato

com o "poemão" Cantar de Mio Cid, formam o patrimônio da cidade. O verso "Pouca coisa Ihe sobrou" (MELO NETO, 1999, p. 148), reiterado na abertura das estrofes 7 e 8 , é significativo quando posto ao lado das homofonias cuidadosamente escolhidas por Cabral, presentes nas expressões: "senão" (versos 26 e 27), "se não" (verso 30) e "seu não" (verso 36). A primeira expressão é preposição de exclusão, mas que paradoxalmente insere na paisagem os restos da cidade: "Pouca coisa Ihe sobrou/ senão ocos monumentos,/ senão a praça esvaída" (MELO NETO, 1999, p. 148). Diante dos restos, a conjunção "se" destaca o "poemão" Cantar de Mio Cid, pois: "pouca coisa lhe sobrou/ se não foi o poemão/ que o poeta daqui contou/ (talvez cantou, cantochão)," (MELO NETO, 1999, p. 148). A narrativa épica Cantar de Mio Cid é também cantochão, poesia sobre a terra, evocando um tempo épico de conquistas que mobilizaram a alta e a baixa nobreza. O canto dá lugar à escrita e à fixação da história dos feitos heroicos de El Cid: "que poeta daqui contou/ (talvez cantou, cantochão), // que poeta daqui escreveu" (MELO NETO, 1999, p. 148-9). Aqui entra em cena uma nova equivalência: a dureza de mão do escritor assemelha-se ao não dito em silêncio, à privação por que passa a gente de Medinaceli, instaurada no mesmo espaço e tempo do eu poético: "com que hoje a gente daqui/ diz em silêncio seu não." (MELO NETO, 1999, p. 149). O jogo de palavras homófonas reforça o paradoxo histórico da cidade, outrora espaço de guerras e conquistas; hoje local ermo que mantém, como única e eufórica memória, a possibilidade de ter sido local de nascimento do autor de Cantar de Mio Cid.

É notório que João Cabral poderia construir versos sobre as incertezas que tantos estudos geraram quanto à origem da autoria do Cantar de Mio Cid ou mesmo sobre a data de escrita da obra, entretanto interessou-lhe a relação da cidade com sua gente, sendo que o ilustre provável autor de Cantar de Mio Cid também é parte dela. A écfrase neste poema tem por função a instauração da memória de um povo outrora heroico, agora em situação de penúria. As batalhas passadas e mesmo o "poemão" não conseguiram amenizar os problemas da cidade. Segundo Riaño Rodríguez 
Princípios ecfrásticos em Paisagens com figuras, de João Cabral

Fabiane Renata Borsato

e Gutiérrez Aja, o provável autor de Cantar de Mio Cid, Pero Abat, “[...] ideó un Cantar siguiendo dos líneas o frentes: la del arquetipo de nobleza, en torno al Cid, respetuoso siempre con el Rey, y la de los nobles castellanos faltos de toda dignidad, los Ansúrez-Beni Gómez, de cuyo linaje descendía el intrigante Pedro Fernández de Castro." (2007, p. 31). Diante de tal contradição histórica e cultural, o poema "Medinaceli" reúne glórias passadas e esvaziamento presente, empregando as imagens do deserto modelo e do tabuleiro bélico para a representação do passado; e as imagens do esqueleto hemorrágico com seus ocos monumentos como figuras do presente. Tais imagens são focalizadas num movimento de descenso que adquire a função icônica de criar relação entre as sucessivas mudanças por que a cidade passou até ser focalizada pelo eu poético de "Medinaceli".

Outro poema que evidencia dois momentos e duas configurações espaciais, uma estática e a outra atuante, é "O Vento no Canavial". O anonimato do canavial e sua feição desprovida de singularidade são descritos nas três primeiras estrofes por meio das figuras da planta sem nome, do mar sem navios, do papel em branco, do lençol aberto, da penugem de moça, da roupa lavada. A condição de equivalência das imagens tem por sustentação a ausência de marcas e intervenções sobre a paisagem homogênea: “Não se vê no canavial/ nenhuma planta com nome,/ nenhuma planta maria,/ planta com nome de homem.// É anônimo o canavial,/ sem feições, como a campina;/ é como um mar sem navios,/ papel em branco de escrita.// É como um grande lençol/ sem dobras e sem bainha;/ penugem de moça ao sol,/ roupa lavada estendida." (MELO NETO, 1999, p. 150).

A estrofe quatro inicia-se com uma conjunção adversativa que Ihe oferece traço palinódico ${ }^{1}$ ao revisar a paisagem anteriormente apresentada e revelar outra face do canavial, somente apreendida pelo olhar sensível sobre as coisas, olhar este capaz de ouvir a melodia oculta no relógio de pulso, ver a paisagem organizada de

\footnotetext{
1 Palinódia é procedimento de revogação do anteriormente afirmado e defendido, sendo termo originalmente ligado à obra de Estesícoro (VI a.C.), autor que revê seus ataques a Helena, inocentando-a na Palinódia e, consequentemente, retratando-se da versão anterior que a descrevia como elemento desencadeador da Guerra de Tróia. A palinódia, portanto, fundamenta-se na retratação espontânea ou coerciva de uma obra ou discurso anteriormente proferido.
} 
uma cidade quando apreendida de dentro de um avião (tema do poema da obra Quaderna, intitulado "De um avião"), as texturas esboçadas nas pedras, as estrelas na bandeira em movimento, o lençol sensível: "Contudo há no canavial/ oculta fisionomia:/ como em pulso de relógio/ há possível melodia,// ou como de um avião/ a paisagem se organiza,/ ou há finos desenhos nas/ pedras da praça vazia." (MELO NETO, 1999, p. 150-1). O agente desta mudança fisionômica é o vento, elemento modificador que retira do canavial sua condição de esvaziamento identitário e Ihe permite adquirir a solta simetria das ondas do mar. $E$ às imagens de objetos inanimados (relógio, cidade, bandeira, lençol) somam-se as imagens "multidão/ lutando na praça cheia" (MELO NETO, 1999, p. 151), voragens, redemoinhos e povo. A écfrase do poema reúne imagens animadas e inanimadas e compreende um campo semântico habitualmente presente na poesia de Cabral - tempo, geografia, erotismo e política -, elementos imbricados cultural e politicamente na manutenção do status quo nordestino.

Ao instaurar imagens e discuti-las verso a verso, ora reiterando-as, ora desdobrando-as em outras e inusitadas imagens, João Cabral promove equivalências e concretiza a écfrase pretendida. Segundo Nunes, o poeta estrutura sua obra em dois polos, da experiência reflexivo-construtiva e da experiência sensível-concreta: "Não deparamos com uma trama de conceitos, mas com uma tessitura de abstração e concretude, que rebate o conceito ao plano da imagem e faz subir a imagem visual a do conceito." (NUNES, 1971, p. 90-1). "O vento no canavial" utiliza o mecanismo da metáfora para construir a écfrase do vento incidindo ou não sobre o canavial. O poema faz equivaler a abstração da écfrase do vento que recai sobre o canavial e, simultaneamente, a concretude da imagem do povo mobilizado em praça pública. Trata-se de imagens mobilizadoras porque animam a paisagem e os homens. $O$ advérbio "Então" confirma a passagem de uma imagem a outra e as relações políticas de implicação entre canavial e povo: "É solta sua simetria:/ como a das ondas na areia/ ou as ondas da multidão/ lutando na praça cheia.// Então, é da praça cheia/ que o canavial é a imagem:/ veem-se as mesmas correntes/ que se fazem 
Princípios ecfrásticos em Paisagens com figuras, de João Cabral

e desfazem,// voragens que se desatam,/ redemoinhos iguais,/ estrelas iguais àquelas/ que o povo na praça faz." (MELO NETO, 1999, p. 151).

\section{"Vale do Capibaribe": assepsia cultural e hídrica}

"Vale do Capibaribe" mantém diálogo com os quatro poemas até então comentados. O percurso do olhar do eu poético sai da topografia e alcança o homem, em sua luta interminável com a terra. Todavia, se Medinaceli apresenta o Cantar de Mio Cid como objeto memorável, o Vale do Capibaribe apresenta assepsia cultural e hídrica; terra marcada pela seca inexorável e por contínua luta pela sobrevivência humana.

Os parênteses do poema emolduram afirmações e interrogações sobre imagens que compõem a écfrase do Vale do Capibaribe. Os primeiros parênteses aportam informação ao que foi dito nos versos anteriores e destacam a seca dos rios e do discurso como o principal problema do local: "(nem mesmo águas ocorrem/ na língua dos rios secos)." (MELO NETO, 1999, p. 152). Esta questão será retomada em obra posterior, $A$ educação pela pedra, no poema intitulado "Rios sem discurso" que, como em "Vale do Capibaribe", reforça a premissa de que o corte do curso dos rios equivale ao corte do discurso, desdobrando a écfrase em duas imagens, do Vale e da produção literária, ambos áridos e escassos na região. Os parênteses seguintes compreendem uma quadra e duas interrogações: "(De que seriam ruína,/ de que já foram paredes?/ Do forno em que o deus da seca/ acendia a sua sede?)" (MELO NETO, 1999, p. 153). Aristóteles previu, no livro III da Retórica, o uso da interrogação como recurso de refutação e demonstração do absurdo da situação ou da contradição argumentativa. Isso evidencia o viés refutativo do poema, sendo a segunda interrogação resposta à primeira pergunta e ao fingimento histórico das ruínas, qual seja, a de que a seca surge como a vilã com poderes divinos a explicar a secura do Vale. 
Princípios ecfrásticos em Paisagens com figuras, de João Cabral

Os parênteses seguintes, como os anteriores, acuram a imagem dos crimes com acentos de gesta, dando-lhes o traço local: "(ou as façanhas cangaceiras)" (MELO NETO, 1999, p. 153). A écfrase parte da descrição topográfico-histórica do Vale do Capibaribe, passa pela literatura de cordel como espaço discursivo sobre os acontecimentos do Vale e chega à história incontável do homem em luta diária contra a seca e a fome: "No mentido alicerce de/ morta civilização/ a luta que sempre ocorre/ não é tema de canção." (MELO NETO, 1999, p. 153).

Nas três últimas estrofes, o poema ressalta a luta entre homem e terra. O campo semântico mobilizado para tal descrição compreende o Vale (deserto, terra, pedra, caliça, absorve), o homem que o habita (sangue, boca, saliva, intestinos) e o teor bélico dessa existência (luta, sangue, vencedor, mata, vencidos, morte). $O$ léxico empregado não gera qualquer estranhamento, mas a forma como foi empregado sim: "É a luta contra o deserto,/ luta em que sangue não corre,/em que o vencedor não mata/ mas aos vencidos absorve.// É uma luta contra a terra/ e sua boca sem saliva,/ seus intestinos de pedra,/ sua vocação de caliça,//" (MELO NETO, 1999, p. 153). A luta não desprende sangue, elemento paradoxalmente ausente dos fatos e presente enquanto léxico; tampouco o vencedor mata alguém, mas os absorve, sendo que este verbo instaura no poema um processo gradativo de corrosão e dissipação da vida, apresentando a atuação da ordem da extensão e da duração temporal, o que gera a imagem de uma luta interminável.

$\mathrm{Na}$ penúltima estrofe, os elementos semanticamente conferidos ao homem estão em concordância com a terra, a quem são atribuídas a boca sem saliva, os intestinos de pedra, a vocação de caliça, tornando clara a relação de implicação que Cabral estabelece entre terra e homem e o resultado insatisfatório dessa relação. 


\section{"Volta a Pernambuco" e "Outro rio: o Ebro": enuncia- ções da paisagem em primeira pessoa}

Os poemas "Volta a Pernambuco" e "Outro rio: o Ebro" apresentam o eu poético em primeira pessoa, respectivamente como observador e como personagem da ação apresentada. A memória do eu poético é ativada para alcançar objetivos distintos: "Volta a Pernambuco" parte dos aspectos particulares das cidades para chegar a um conceito genérico de cidade; "Outro rio: o Ebro" tematiza o próprio conteúdo e trajeto para, em seguida, reconhecer sua importância histórica e seu valor épico, traço que o distingue do rio Capibaribe, da obra $O$ rio (1953), falto de qualquer possibilidade de atuação heroica.

"Volta a Pernambuco" faz uso da memória associativa para construção da écfrase. O eu poético encontra-se em Pernambuco, a contemplar a maré baixa, o mangue, as várzeas, a cana estendida ao sol. Enquanto realça esses elementos da paisagem, a memória ativa o recurso da associação e as equivalências são enunciadas. As mais diversas localidades são recordadas pelo eu poético: a baía de Dublin, Albufera de Valência, as janelas de Chelsea, os trigais de Guadalajara. Sendo assim, as quatro primeiras estrofes realizam a associação de espaços singulares que guardam semeIhanças entre si, enquanto as cinco estrofes seguintes apresentam um conceito genérico de cidade, pois, segundo o eu poético, as cidades são semelhantes no calçamento, no fluxo de trabalhadores pelas ruas e no fato de que "é um crime/para o povo estar na rua," (MELO NETO, 1999, p. 165).

O movimento do poema é similar ao realizado nos demais poemas comentados, vai da paisagem panorâmica aos veios das ruas das cidades, por onde circulam os trabalhadores e o povo. Entretanto, enquanto os outros eus poéticos dos poemas comentados mantinham seus olhares sobre o traço local, "Volta a Pernambuco" amplia o foco até alcançar um conceito geral de cidade, em que o trabalho humano promove marcas no pavimento, que são 
descritas como nódoas de vida humana. Irlanda, Espanha, Inglaterra, Brasil, e mesmo as cidades de países não citados, guardam consigo esta semelhança, sintetizada no crime da exploração de seus trabalhadores. Para denunciar essa situação, Cabral percorre campos semânticos díspares como crença religiosa (procissões, andor), criminalidade (crime), arquitetura das cidades (lajes, ruas, pedras do calçamento, pedras do pavimento, cimento), anatomia e tráfego (artérias), comércio (produto, mercado). Estes elementos predominantemente culturais apresentam relações de contiguidade, sendo que nas quatro primeiras estrofes o olhar do eu poético concentra-se na paisagem, isenta da intervenção humana, e nas cinco últimas estrofes o foco é o povo trabalhador. Os termos "suor" e "nódoa", fundamentais para a compreensão da crítica à condição de existência da classe trabalhadora nas cidades de vários países, estrutura-se metonimicamente. A expressão "suor do rosto" é desconstruída por Cabral e embaralhada para formar a inusitada expressão "vão levar o seu produto/ aos mercados do suor." (MELO NETO, 1999, p. 164), deixando como elipse os termos venda e lucro, intenções dos mercados que armazenam os produtos transportados com o sacrifício e o suor dos trabalhadores. Numa relação de implicação, construída de modo complexo, Cabral substitui mercadoria por suor e promove a equivalência entre os termos. Quanto à palavra "nódoas", podemos refletir sobre sua relação com "suor", já que a passagem dos carregadores de produtos equivale ao trânsito dos fiéis carregando o andor, imagem que iguala os sacrifícios e as marcas por eles deixadas nas pedras do pavimento, máculas na história dessas cidades e de seus crimes contra o povo.

À maneira do poema O rio, obra publicada em 1953, vemos no poema "Outro rio: o Ebro", o eu poético peregrino a descrever a paisagem de um lugar intersticial e contíguo a ela. O pronome "outro" é o termo que implica a travessia dos dois rios: Capibaribe, eu poético presente no poema $O$ rio, e Ebro, eu poético do poema de Paisagens com iguras. Assim como no livro anterior, o rio no poema "Outro rio: o Ebro" descreve seu percurso, sendo similar à 
Princípios ecfrásticos em Paisagens com figuras, de João Cabral Fabiane Renata Borsato

travessia do Ebro e a do rio Capibaribe pela questão da seca e da ausência de manutenção da vida às suas margens.

O Ebro inicialmente apresenta seu conteúdo: esqueleto de animal morto de sede, pedra e cal desaparecidos pela seca, e ainda relata sua passagem por estreitas hortas, casas isoladas na paisagem, vilas desmaiadas, torres de barro mouras. É da ordem da intensidade a seca em terras por onde passa o Ebro: “O gesso também perece,/ não morde mais como a cal./ Dir-se-ia que até a pedra/ morreu de sede e de sol." (MELO NETO, 1999, p. 165). E se o conteúdo do rio é desta ordem, não é menos intenso o resultado da seca na paisagem panorâmica: as hortas são estreitas, a vida habita corredores estreitos, as casas são extraviadas no deserto das terras de Aragão, a água do rio flui como linha de carretel, sendo água opaca ("água de cego cristal"), o leito do rio é largo em contraposição ao fio de água que por ele circula. Assim como o Capibaribe, o rio Ebro descreve seu percurso épico e, apesar das condições adversas, ele insiste em regar o "duro chão mineral" das terras ossudas de Aragão. Ele descreve também, euforicamente, a condição de trincheira quando da batalha do Ebro, na Guerra Civil Espanhola, porque sua atuação é da ordem da resistência.

Esse aspecto do rio Ebro o distingue do rio Capibaribe. Enquanto o segundo tem sua travessia "épica" motivada pela possibilidade de registrar, no canto poético, a saga da gente que às suas margens sobrevive e morre; o rio Ebro está focado em si mesmo, em suas feições humanas e proezas de "líquida espinha dorsal". Ele se autodescreve como elemento de manutenção da sobrevivência, questão jamais cogitada pelo rio Capibaribe que sofre penas similares às da gente que com ele emigra.

\section{"Imagens em Castela" e a discussão de imagens}

"Imagens em Castela" também dá ênfase à paisagem para tratar da condição humana. A écfrase, neste poema, oscila entre 
descrições etimológica, metafórica e metonímica da paisagem de Castela. O poema apresenta os alicerces de construção da écfrase ao promover, durante vários versos, a discussão dos signos capazes de "pintar" a paisagem: "Se alguém procura a imagem/ da paisagem de Castela/ procure no dicionário:/ meseta provém de mesa.//(...) E quando não é a mesa/ sem toalha e sem terrina,/ a paisagem de Castela/ num grande palco se amplia://" (MELO NETO, 1999, p. 149).

O percurso do eu poético vai da informação etimológica da geomorfologia de Castela, assume a imagem da mesa para descrever os horizontes amplos de Castela, passa à imagem da casa e do cão, por implicação com o termo mesa, e alcança a imagem do palco teatral, cujos espectadores são o cão e o vento anteriormente contíguos à imagem da casa e, neste momento, nos versos retomados: "palco raso e sem fundo,/ palco que só fosse chão,I agora só frequentado/ pelo vento e por seu cão." (MELO NETO, 1999, p. 149). Cabral faz da écfrase um espaço de discussão da imagem para dar a ela traço mais preciso e, ao poema, caráter metapoético. Para isso focaliza a paisagem em sua lateralidade ("É uma paisagem em largura, / de qualquer lado infinita."), em sua horizontalidade ("É uma mesa sem nada/ e horizontes de marinha" e "no palco raso, sem fundo,/ só horizonte, do teatro"), em sua interioridade e ausência de verticalidade ("posta na sala deserta/ de uma ampla casa vazia,/ casa aberta e sem paredes,/ rasa aos espaços do dia.// Na casa sem pé-direito,"), procurando dispor os elementos constituintes desse cenário para que a palavra equivaIha às imagens dispostas na paisagem. O poeta seleciona o signo que possa construir a paisagem poética de Castela: “No mais, não é Castela/ mesa nem palco, é o pão:/ a mesma crosta queimada,/ o mesmo pardo no chão;" (MELO NETO, 1999, p. 150). Esta estrofe une os dois recursos metapoéticos, a écfrase e a palinódia, ao negar o anteriormente afirmado para encontro da imagem mais adequada ao princípio ecfrástico.

O pão é imagem discutida sob vários ângulos: por semelhança de sua superfície de crosta queimada com o chão pardo de Cas- 
Princípios ecfrásticos em Paisagens com figuras, de João Cabral Fabiane Renata Borsato

tela; por sua interioridade paradoxalmente seca e úmida como as terras de Castela; pela maciez sofrida, sendo o primeiro termo atribuído a pão e o segundo ao trabalho manual do homem de Castela. A imagem "maciez sofrida" reitera a écfrase por procedimento metonímico, em que os semas de um elemento são atribuídos ao outro e vice-versa, numa relação de implicação que gera a imagem híbrida do pão-homem-Castela. Ao atingir a interioridade do pão, o eu poético chega ao conteúdo de Castela, formado por "homens de pão escasso/ sua calada condição." (MELO NETO, 1999, p. 150). Esta imagem surpreende porque promove certa ruptura: os versos anteriores propendiam à descrição objetiva da topografia de Castela e a presença do homem e de sua difícil condição não estavam no horizonte de expectativa do leitor. Por outro lado, todas as palavras selecionadas para a composição de Castela estão num campo semântico natural à imagem final do homem de pão escasso, vivendo numa paisagem reduzida ao mínimo. Ademais, o título do poema não engana. Não se trata de imagens de Castela, mas de imagens em Castela, sendo fundamental a preposição para revelar o enfoque sobre os elementos de composição do espaço, evitando as fotografias superficiais, passíveis de ilusão e engano.

\section{“Duas paisagens”, poema-síntese}

O livro Paisagens com figuras é concluído com "Duas paisagens", poema-síntese das topografias da Espanha e de Pernambuco. Focando nas dessemelhanças, o eu poético desconstrói imagens distorcidas de Pernambuco por meio da comparação com a imagem de Teresa, La Ben Plantada, personagem do romance do catalão Eugenio D'Ors.

O poema apresenta duas écfrases que aproximam o literário e o geográfico. Uma imagem, compreendida entre as estrofes um e três, descreve a sobriedade, a lucidez e a proporção harmônica da região da Catalunha, traços aprendidos do ritmo feminino de 
Princípios ecfrásticos em Paisagens com figuras, de João Cabral

Teresa, de D'Ors. A outra, iniciada na estrofe quatro, oferece protagonismo a Pernambuco, dando à écfrase o papel de descrevê-lo por contraposição a Catalunha e Teresa.

A primeira écfrase traça correspondências entre a paisagem e a personagem romanesca, sendo que o intercâmbio lexical promovido nos versos acima citados constrói simultaneamente as duas imagens, de Catalunha e de Teresa. O espaço geográfico medido, cuja topografia apresenta a harmonia das proporções e formas, equivale à protagonista Teresa, do romance de D'Ors: "no ritmo feminino/ de colinas e montanhas/ que lá têm seios medidos." (MELO NETO, 1999, p. 166).

Pernambuco é estado masculino, duro, distinto dos demais estados nordestinos por não conter traço de feminilidade: "é um Estado masculino/ e de ossos à mostra, duro," (MELO NETO, 1999, p. 166). Pernambuco apresenta lucidez e medida como Catalunha e Teresa, mas enquanto para os últimos a lucidez provém da cultura e a medida advém da consciência, para Pernambuco, lucidez e medida advêm da fome e da carência. Enquanto Catalunha tem por mito a Ben Plantada que lhe dá raízes culturais e memória; Pernambuco teria por alegoria o Mal Adubado, de modo que a ausência do adubo é o que impede seu desenvolvimento, sua harmonia formal, social e política.

O poema "Duas paisagens", ao contrapor o feminino e o masculino das formas descritas, se fará emblemático na poesia de Cabral. Os livros subsequentes retomarão a imagem contrapontística e fundamentarão as écfrases da Espanha e de Pernambuco na dicotomia feminino e masculino.

\section{Algumas considerações finais}

Retomando o que inicialmente foi comentado sobre os conceitos e polêmicas da écfrase, é notório que Cabral, em Paisagens com figuras, não descreve uma obra plástica ou arquitetônica, confor- 
me concepção clássica de écfrase que pressupunha a intenção de imitar com palavras um objeto das artes plásticas, mas apresenta espaços geográficos de duas localidades que guardam entre si semelhanças e dessemelhanças, Pernambuco e Espanha. A écfrase, nesta obra, é procedimento de leitura da topografia, história, política e condição humana das localidades, é ainda a apreensão, por enquadramentos panorâmicos ou de detalhe, da condição social e cultural dessas regiões.

Ao delinear a localidade, representando-a no poema por metáforas e metonímias, João Cabral promove associações por equivalência e por implicação (dispostas de modo prismático), o que resulta em retratos das regiões e de seus habitantes tomados de ângulos diversos.

As paisagens empíricas da Espanha e de Pernambuco são apreendidas pelo poeta em contínuo processo de aprendizagem do objeto e da linguagem que o representará. Em lugar de "pintar" estas paisagens, Cabral as transforma em linguagem poética por meio da descrição, da discussão de imagens e da intensificação de alguns aspectos para o alcance da intenção crítica e anti-ilusionista do poema em relação aos problemas vivenciados pelas figuras das paisagens.

A écfrase adquire intenção sistêmica na obra de Cabral. Ao poema cabe selecionar e combinar as palavras para alcançar a linguagem poética em conjunção com o princípio ecfrástico. O desafio que a paisagem impõe ao poeta não é de caráter empírico, mas conceitual. As paisagens e suas figuras, inclusive as humanas, mantêm entre si relação complexa de equivalência, contiguidade e contraste.

Os eus poéticos dos poemas analisados observam, registram, contemplam, examinam, evocam outros tempos e espaços, empreendem associações entre lugares e coisas: "a memória deixa de ser o depósito de evocações subjetivas para transformar-se em fonte de articulação entre referências externas desvinculadas espacial e temporalmente, mas atadas pela captura de seus traços comuns." (SECCHIN, 2014, p. 102). A ideia de imitação inocente não procede mediante a consciência da "ficción de una écfrasis, una 
Princípios ecfrásticos em Paisagens com figuras, de João Cabral Fabiane Renata Borsato

imitación ilusoria de lo que no existe fuera de la creación verbal del poema."(KRIEGER, 2000, p. 150). Compor quadros crítico-reflexivos sobre a condição precária de homens em luta contra paisagens hostis e conhecer linguagens e processos de composição de outros artistas são fundamentos da poética de Cabral.

O potencial da écfrase praticada pelo poeta promove a transição das paisagens da experiência prévia para a concretude da linguagem poética, local em que a palavra é praticada com rigor e consciência de suas potencialidades e limites. Consciência adquirida com outras vozes de poetas e demais artistas, como a do hortelão de Orihuela, Miguel Hernández, de quem o eu poético descobre uma edição incômoda que "igual que árvore amputada,/ ganhara gumes de pedra." (MELO NETO, 1999, p. 156). A écfrase é, sem dúvida, um dos fundamentos da poética da aprendizagem desenvolvida obra a obra, verso a verso, pelo poeta pernambucano João Cabral de Melo Neto.

\section{Referências Bibliográficas}

ARISTÓteles. Retórica. Tradução Edson Binı. São Paulo: Edipro, 2011. BARBOSA, João AleXANdre. O disCURSO da linguagem; A poesia da linguAGem. In: BARBOSA, João AleXANdRe. A Imitação pela forma: uma leitura de João Cabral de Melo Neto. São Paulo: Duas Cidades, 1975. P. 129-155; 211-228.

FRIAS, Joana Matos. Écfrase: 10 aporias, Revista elyra: a Écfrase na poesia MODERNA E CONTEMPORÂNEA, V.1, N. 8, P. 33-40, DEZ. 2016.

JAKOBSON, ROMAN. À PROCURA DA ESSÊNCIA DA LINGUAGEM. IN: jakobson, Roman. Linguística e Comunicação. São Paulo: Cultrix, 1995. P. 98-117.

KRIEGER, MurRay. El PROBLEMA de LA ÉCFRASIS: IMÁGeneS Y PALABRAS, ESPACIO Y TEMPO - Y LA OBRA LITERÁRIA. IN: MONEGAL, ANTONIO (ORg.). LiteratuRA Y PINTURA. INTRODUCCIÓN, COMPILACIÓN DE TEXTOS Y BIBLIOGRAFIA ANTONIO Monegal. Madrid: Arco Libros, 2000. p. 139-160. 
Princípios ecfrásticos em Paisagens com figuras, de João Cabral Fabiane Renata Borsato

MElO Neto, João Cabral de. Paisagens com figuras; Uma faca só lâmina. In: Melo neto, João Cabral de. Obra completa. Org. Marly Oliveira. 3 ed. Rio de Janeiro: Nova Aguilar, 1999. P. 145-167; 203-215.

Melo neto, João Cabral de. Obra completa. Org. Marly Oliveira. 3 ed. Rio de JaNeiro: Nova Aguilar, 1999.

MONEGAL, ANTONIO. DiÁlOgo y COMPARACIÓN ENTRE LAS ARTES. IN:

MONEGAL, ANTONio. (Org.) Literatura y PintURA. INTRODUCCIÓN, COMPilación de textos y bibliografia Antonio Monegal. Madrid: Arco Libros, 2000. P. 9-21.

Nunes, Benedito. João Cabral de Melo Neto. Petrópolis: Vozes, 1971.

Platão. A República. Introdução, tradução e notas Maria Helena da Rocha Pereira. Lisboa: Calouste Gulbenkian, 2001.

Riaño RodrígueZ, Timoteo;GutiérRez aja, María del Carmen.

Cantar de Mío Cid. Texto modernizado. Alicante: Biblioteca Virtual Miguel de Cervantes, 2007. Disponível em: http://www.Cervantesvirtual. COM/ND/ARK:/59851/BMCQJ7W3. ACESSO EM: 26 MAIO 2019.

RIFFATERRE, Michel. La ILUsión de ÉCFRAsis. In: MONEGAL, ANTONIO (ORG.). LITERATURA Y PINTURA. INTRODUCCIÓN, COMPILACIÓN DE TEXTOS Y BIBLIografia Antonio Monegal. Madrid: Arco Libros, 2000, p.161-183.

SeCChin, Antônio Carlos. A natureza rarefeita [Paisagens com figuras]. in SeCChin, Antônio Carlos. João Cabral de Melo Neto: uma fala só LÂMInA. São Paulo: Cosac NaIFY, 2014, P. 100-112. 